\title{
Transducin-Like Enhancer Protein 2
}

National Cancer Institute

\section{Source}

National Cancer Institute. Transducin-Like Enhancer Protein 2. NCI Thesaurus. Code C115082.

Transducin-like enhancer protein $2(743 \mathrm{aa}, \sim 80 \mathrm{kDa})$ is encoded by the human TLE2 gene. This protein is involved in Notch and Wnt signaling pathways and transcriptional repression. 